DOI: $10.24234 /$ wisdom.v18i2.476

Oleh TYSHCHENKO,

Igor KOROLYOV,

Oleksandra PALCHEVSKA

\title{
CULTURAL AND COGNITIVE STRUCTURE OF THE OMEN: EPISTEMOLOGY, AXIOLOGY AND PRAGMATICS
}

\begin{abstract}
The article presents the cognitive categorization principles in different ritual and non-ritual situations. The semantics, structure and pragmatics of omens and the related cultural concepts in the archetypal world model are based on ethnosemiotic and cognitive analysis aspects, folklore pragmatics elements, and the cultural text verbal magic. The omens convey such significance for folk culture oppositions as good-evil, life-death, top-bottom, male-female, etc., as well as the connection with various traditional culture codes action, object, zoomorphic, artifactual, sociomorphic, verbal and so on. As a holistic cultural and cognitive macrosign, taken in the unity of functions, conceptospheres and semantic oppositions, the omen is organized according to the principle of a situation-event cognitive cluster - action - reaction, forecast - belay, embodied in profiling a cultural prescription or taboo. As a cultural and folklore genre, the omens are based on the collective experience. They are fixed in the collective memory as a correlation of two situations (events) in causal connection (predictive - predictable) fixed by folk tradition. The primary attention is paid to the pragmatic and axiological properties of the omens, epistemological and ontological principles of their organization in the compared Slavic and non-Slavic linguistic (English) cultures.
\end{abstract}

Keywords: cognitive structure of the omen, forecast, frame, conceptosphere, axiology, chrononym, calendar saying, semantic attraction.

\section{Introduction}

In modern culturological studies, the leading place is occupied by folklore pragmatics. The small folklore forms structure, semantics and symbolism, which are orders, verbal formulaswishes, dream books, beliefs, ritual sayings, signs, etc., elements of the so-called verbal ritual code. Important in this regard are verbal and pragmatic formulas for the addressee - amulets, warnings, their intention, including warnings, threats, insults, intimidation, flattery, farewell etc. (Levkievskaya, 2002; Chudzik, 2002; Korolyova \& Korolyov 2020). The genesis of small genres, in turn, is closely linked to the reconstruction problem - the depth of genre immersion in an archaic cultural state.
Works of famous ethnologists of the twentieth century such as E. Durkheim, O. Hubert, M. Mohs, B. Malinowski, L. Levi-Bruhl, E. League confirm that the reality conceptualization and categorization methods inherent in different primitive cultures cannot be characterized without different views on the primitive and modern man's world, on the one hand, and without the cultural context in which they act, on the other. Observers are deforming and almost always distorting institutions and beliefs about which they write while inadvertently use the concepts they are accustomed to (Levy-Bruhl, 1994, p. 332).

In this regard, folklore, small forms (especially ritual wishes, omens, divinations and foresight, etc.) are highly conservative and constitute a set of almost "fixed" formulas and motifs: hen- 
ce arises their similarity in different folklore traditions. As a result, it is necessary to reconstruct the ritual and its semiotic space consistently.

Omens, along with orders, ritual dialogues, wishes, spells, are not just a verbal text, but a text-rite, text-ritual, with verbal and effective (action) plans that are in inseparable unity with the ritual time, marked in the rite loci, subject, functional, character, etc. codes (Vinogradova, 2004, p. 217) and correlated with the language magical function and the archetypal world model. Russian ethnographer A. Baiburin sees in the archetypal features thinking reconstruction the integrity of archaic culture, the indivisibility of sign systems, the postulation of a specific rite metalanguage, which determine the mythoritual scenario, create the impression of different stereotyping experience mechanisms (Bayburin, 1990, p. 3). Scholars define them as "stereotyped ritual or magic human behaviour" (Vinogradova, 2004; Chudzik, 2002), "situational phrases genetically related to ritual actions" (Zhuykova, 2007), "pragmatic clichés-formants" (Balandina, 2003).

As noted by T. Agapkina and O. Belova, typologically, signs are associated with other forms and types of traditional predictions (omens, dreams, signs, etc.), as well as with divination. In omens, such significant national culture oppositions as good-evil, life-death, top-bottom, goodbad, man-woman are realized (Agapkina \& Belova, 2009, p. 279).

L. Vinogradova attributes these texts to the border folklore "microgenres", which are seen as all sorts of superstitious and meteorological signs, economic and household recommendations, "rules", prohibitions, actions and customs motivations, interpretations, beliefs and other similar texts of instructive-prognostic orientation. The latter are characterized by a high structure stability degree, which allows preserving the archaic creativity levels motifs and symbols. These units are essential for understanding and deciphering ritual-magical practice, in a certain ability to clarify the symbolic actions, motivations and meaning (Vinogradova, 1988, p. 278).

The folk forecast, as ethnographers have repeatedly emphasized in their studies, is formed by "everyday (customary, practical, mass) consciousness, which as a result of observations, generalizations or mythological and superstitious ideas predicts the future situation" (Ivanova, 2005, p. 16). Recently, there have been done omens' complex studies concerning different linguistic cultures, in which the folk omens semantics is associated with various life, custom and ritual realities (Fattakhova, Kulkova, \& Tuganova, 2014).

An omen is a stable connection between two objective reality phenomena, one of which is understood as a sign, and the other as its interpretation, usually done in the form of a forecast for the future; linguistic (in the form of an aphorism, paremia) representation of this connection. As a rule, the omens include those interpretations that are based on the collective experience and are fixed in the collective memory (Agapkina \& Belova, 2009, p. 279). A similar definition is offered by B. Norman and N. Rainokhova, according to which an omen is a correlation of two situations (events) fixed by folk tradition, which are arbitrarily placed in a causal connection. Generally, this is a manifestation of verbal mythology and, at the same time, part of the everyday culture (Norman \& Raynokhova, 2017, p. 6).

\section{From the History of the Omens' Study and Their Classification}

According to the Slovak researcher Z. Profantová (1986), the oldest signs are known from the Sumerian epic "Gilgamesh", observations of the Babylonian Chaldeans and ancient Egyptians, from the Assyrian cuneiform tablets (p. 9) etc. Meteorological observations were already known in the ancient Greece and Rome era, in particular, were presented in the "Odyssey" by Homer and "Theogony" by Hesiod. (eg: Když se vynoři souhvězdi Plejád, dcer Atlase, tedi začni žatvu, ale oř, když jde okolo (Profantová, 1986, 
p. 9)). In this regard, the work "On the signs of the wind", attributed to Theophrastus, is interesting, where, in addition to numerous prognostic material, a meteorology state description as an empirical science in the classical period of Greek "natural philosophy" is given (Profantová, 1986, p. 9).

In the oldest East Slavic chronicles, we can meet a word omen used as a term, which is given, in particular, in the ethnographic collection of I. M. Snegiryov. In V. Dahl's, F. Buslaev's, M. Sumtsov's folklore works the "omen" is used in the same context as the terms "belief", "superstition". O. M. Afanasyev distinguishes two types of conditional-consequential texts: derived on real observations basis as well as those derived on the basis of mythological ideas (Afanasyev, 1995, pp. 15-23).

In the field of Ukrainian folklore, such scholars, collectors of folk poetry, as V M. Hnatyuk ("Selected articles on folk art", 1966), M. Yu. Rusyn ("Folklore: traditions and modernity", 1991), L. S. Khrenov ("Folk signs and calendar", 1991), I. I. Ogienko (“Ukrainian culture”, 1992), V. T. Skuratovsky ("Moonlight”, "Rusalii”, 1993). ${ }^{1}$

\section{Theoretical Background, Methodology and Description of the Issue}

In contrast to the literature, the folklore tradition is an example of semiotic programming, particularly at the subject-object level. It is interesting to note that folklore historical and poetic studies allow us to consider it as an independent (in terms of semiotics - self-regulating) poetic structure that establishes subjective systemic connections with the real world. A systematic approach to understanding the folklore meaning brings to the foreground the problem of the subject creator as a certain consciousness form bearer (in this case - mythological).

For a detailed review of this issue, see: Mashtakova, 2013, p. 32.
Some phenomena were based on mythological ideas about the world around. Since in the primitive man's life things were endowed with a magical function, the whole environment became a source of many predictions and signs that concerned the life of man himself, his destiny, temperament (Afanasyev, 1995; Potebnya, 1989; Tolstoy, 1995a, and others). ${ }^{2}$ Such omens were called superstitious, irrational, unreal, supernatural, eg: Kdo začíná sekati v pátek, nedostane suchého stébla domi̊; Oheň od hromu uhasi se jen mlékem (Čečetka, 1900, pp. 254-255); Kamen zjeřábího hnízda vložený do lože rodičky usnaď̌uje porod (Svoboda, 1901, p. 311).

However, in the "archetypal model of the world", there was no division of omens into trustworthy - not credible, for the man gets to know the world in general, not from his own experience, and quite limitedly - from collective experience, but apprehends it as something immanent, internal (Tsivyan, 1985, pp. 154-179).

The "archetypal man entrusts himself to the eternal and unchanging world, in which everything is defined and where his well-being is ensured by the unquestioning observance of the socalled "code of rules". Thus, multiple predictive observations of the same type were memorized, worded in clichéd form, and had passed down from generation to generation as cognitive and value experience structures. Some believe that the omen is the remnants of "ancient symbolism, which established links between the physical and spiritual worlds" (Zhayvoronok, 2006, p. 481).

In the same series is a set of rules governing a significant daily human behaviour part. Historically, the emergence of many signs can be explained by the connection with the archaic belief system. Thus, it is generally accepted that one should not greet or say goodbye across the doorstep. The doorstep of the ancient Slavs was considered the habitat of an evil force - the domovyk (household spirit). The ban on whistling or a disapproving attitude to whistling (Russian:

2 For a detailed review of this issue, see: Pohribna, 2011, p. 13. 
Don't whistle or there will be no money) dates back to the notion of the pagan god Posvist (Whistle) and some dangerous evil spirits (Zelenin, 2014).

The archetypes' presence is a typological characteristic of the omen. According to Jung, there is no significant idea or view without their historical prototypes, which ultimately reach the archetypal preforms, the essence of which was outlined when consciousness has not yet thought, but perceived (Jung, 1991, pp. 137-144). Special significance is given to the connection of omen semantics and pragmatics and prophecies as cultural texts with archetypes and various symbolic reinterpretations connected with them because each phenomenon is immersed in the existence of the beginning element (Petrichenko, 1999, pp. 87-90).

In the most common sense, the image archetypes are an ancient source, specific images, common (or similar) for the vast majority of humanity. These images may be the same or may differ in the means of expression in different languages. Still, structurally they form specific prototypes or can be reconstructed as prototypes or as omen profiles.

The cultural profiling of concepts within the symbolic stereotypes theory is discussed in the works of Polish ethnolinguistic orientation representatives (Grzegorzczykowa, 1998, p. 12; Muszyński, 1998, p. 22). In this approach, the water profile in the cultural text contains the following manifestations: cosmogonic (water - the basis and source of life), a means of purification (catarrhal), a symbol of erotic experiences in traditional folk culture (Grzegorzczykowa, 1998, p. 12). Profiles function in two ways: they either openly enter the text, which directly describes the rite or part of it, the performer or outwardly have no material expression, exist as certain conventionally fixed mental formations - non-verbalised mental sign correlates in the cultural text.

Archetypes are constituent elements of a pragmatic signs' system. The world perception duality in the pre-Christian era explains the ar- chetypal symbols of water, earth, fire, air (wind) ambivalence, the last acted in two main hypostases - creative, life-giving force and destructive, ruining force.

M. I. Shakhnovich proposes to classify the omens by the magic types: industrial (hunting, fishing, agricultural, pastoral, craft), meteorological, etc. I. Yu. Nazarova (2007), T. B. Shchepanskaya (2010) and others are conducting their research in the same direction (as cited in Zavyalova, 2013, p. 188).

V. I. Chicherov (1957) divides the omens into household ritual and labour calendar (p. 235), synthesizing the indicated approaches. Another systematization experience based on the reliability of the reported facts is taking into account the form origin. A. N. Afanasyev (1988) divides omens into two types: derived from actual observations; superstitious, based not on experience but mythical representation (p. 63). His followers distinguish "authentic" omens, confirmed by experience, practice, and "magical", based on the belief in the existence of the supernatural force. Occasionally the third group is mentioned - "erroneous" omens, created in the course of incorrect observations (as cited in Zavyalova, 2013, p. 189; Shakhnovich, 1984, p. 150).

V. K. Kharchenko specifically stipulates this point: "Folk omen... verified by repeated observations or traditionally accepted and passed down from generation to generation events prediction" (Kharchenko, 1992, p. 78; Zavyalova, 2013, p. 189).

The Czech and Slovak cultural traditions and folklore are also dominated by the thematic principle of the feature division: economic and weather (F. Bartoš, J. Spilka), agronomic and meteorological (M. Čechová), economic and meteorological (L. Havelková), calendar and chronometric (Z. Vaški̊), calendar and symptomatic (not related to the calendar, statements about the weather, which contain common signs-symptoms) (Z. Profantová), etc. (Pohribna, 2011, p. 8). Thus, the Slovaks and Poles have the following signs: Suchý marec, mokrý máj, bude žito 
ako háj (Engl. Dry March, wet May, rye will be thick as a grove); Suchý marec, studený apríl, mokrý máj, bude v stodole raj (Dry March, cold April, wet May - the paradise, will be in the barn) (Záturecký, 2018, p. 513), Chladný máj naplñuje stodoly (Cold May fills the barns (Záturecký, 2018, p. 514), Ked' na Medarda prší, bude pršat'za štyridsat' dní (When it comes to Medarda, it will rain for forty days) (Záturecký, 2018, p. 515). Compare Polish predictions: Kto sieje w marcu ten zbiera w garncu (He who sows in March gathers in a pot), A kto sieje w maju, ten zbiera w jaju (And he who sows in May, gathers in an egg). Polish Ciepte deszcze w kwiecień rokuja pogodna jesień (Krzyżanowski \& Swirko, 1970, p. 264), Gdy kwiecień chmurny, a maj z wiatrami, rok żyzny przed nami, Gdy w końcu kwietnia deszcz porosi, błogosławieństwo polom przynosi, Jeżeli w kwietniu pszczoły nie latają, to długie chłody się zapowiadają (Krzyżanowski \& Swirko, 1970, p. 264), Kiedy w kwietniu słonko grzeje, rolnik nie zubożeje (Krzyżanowski \& Swirko, 1970, p. 265).

Polish Gdy w marcu niebo od południa ryknie, rok wszego dobra w żyzności uniknie (Krzyżanowski \& Swirko, 1970, p. 397), Gdy w marcu od południa ryknie, wielki ci z tego urodzaj wyniknie, Jak się w marcu rola kurzy, rolnik się nie dłuży (Krzyżanowski \& Swirko, 1970, p. 398), Marzec, co z deszczem chadza, mokry czerwiec sprowadza, Marzec czy słoneczny, czy płaczliwy, listopada obraz żywy (Krzyżanowski \& Swirko, 1970, p. 399), W marcu kto siać nie zaczyna, dobra swego zapomina (Krzyżanowski \& Swirko, 1970, p. 400), Koniec marca - ni ma co dać do garca (Krzyżanowski \& Swirko, 1970, p. 398).

British omens concerning the month of the year are as follows: The day of the week on which the 3rd of May falls is unlucky for taking account of cattle on a farm; Cold May, Long corn, short hay (Rut.). A wet May, Maks langtail'd hay (Yks.). A lecky [showery] May, plenty o' hay, A lecky June, plenty o' corn (Nhb.). A wet May and a Winnie [windy], Makes a fou stack- yard and a finnie [plentiful] (Sc. n.Cy.) (Wright, 1913, p. 318). Cool and evening dew in May brings wine and much hay.; For an east wind in May 'tis your duty to pray; Snowstorm in May Is worth a waggon-load of hay; Many thunderstorms in May. And the farmer sings, "Hey! Hey! "; The more thunder in May, the less in August and September (Inwards, 1898, p. 32).

It should be emphasized that, unlike omens, texts of magical actions are modally marked microtexts (formal indicators of such constructions are descriptors of the category of state - worth, belongs, can, can't, if You want, as You wish, performative and imperative action elements verbs etc.), in which the first part (motivated) has functional features of advice or prohibition, and the second (motivating) reports the consequences (forecast). Russian researcher M. A. Kulkova applied the theory of directive acts to the omens' semantic and pragmatic features analysis, distinguishing, in particular, prescriptive signs, which attribute a specific action to the addressee (order, request, prescription, prohibition) and suggestive, expressing warnings, proposal, etc. (Kharchenko \& Tonkova, 2008, p. 33).

L. N. Vinogradova refers the last to the border folklore "microgenres", which are various superstitious and meteorological omens, economic and household recommendations, "rules", prohibitions, actions and customs motivations interpretations, beliefs and other similar texts of instructive and prognostic orientation.

The latter are characterized by a high structure stability degree, which allows preserving the creativity of archaic levels motifs and symbols. These units are important for understanding and deciphering ritual-magical practices in a certain ability to clarify the symbolic actions, motivations and meaning (Vinogradova, 1988, p. 278).

A similar typology of omens has been suggested by some ethnolinguists, who emphasize that thematically the omens represent the main traditional community spheres: weather, economy, to a lesser extent, the sphere of everyday life, family relations and personal characteristics. 
At the same time, the weather and economic omens have a predominantly rationalist basis, when the household and family are mostly superstitious (Agapkina \& Belova, 2009, p. 279). A special group consists of calendar omens based on the natural phenomena interpretation timed to the folk calendar specific dates (p. 279).

O. B. Khristoforova (1998) proposes to divide folk omens into omens-forecasts and omensinterpretations and identifies two main pragmatic functions of omens: for the omens-forecasts, it is the prognostic function, for epy omens-interpretations - informative and warning (pp. 1-2).

Thus, the acts of warning are often combined with the concept of the Road: As the owner or one of the family goes on the road, you should not immediately close the gate behind him (Zhayvoronok, 2006, p. 118).

Some subfunctions of omens can be determined:

- prognostic, for example, associated among the Western Slavs with the so-called Wolf days and months (Great Slavic Calendar, 1913, p. 150); Jaké povětři ve vlčím mésíci bývá, takové též bývá vbřeznu (What the weather is like in the Wolf month, the same will be in March) (Vašků, 1998, p. 312); Je-li na den sv.Marka rosa, podaři se prosa (Bartoš, 1892, p. 80), cf. a number of Slovak omens about the death of old people in March (March takes away old people, in March they have to gather, clean up): Ide marec, poberaj sa starec, Marec, nejeden v ňom umrie starec, Marec, poberaj sa starec $\mathrm{v}$ tanec, Príde marec, zomrie starec, V marci umierajú starci. Adalb. Marzec 3. (Záturecký, 2018, p. 513), Polish: Gdy przyjdzie marzec, umrze niejeden starzec (Krzyżanowski \& Swirko, 1970, p. 397).

- cumulative, ie the function of knowledge accumulation (Bartoš, 1892, p. 79); Vrána kvače - bude déśt (Čelakovský, 2000, p. 529)), often of a special type - with an irrational element (Hezký den na sv. Jakuba prislibuje mnogo ovoce (Great Slavic Calen- dar, 1913, p. 151); Slovak. Na Petra Pavla seje pánboh prvé hríbiky (God sows the first mushrooms on Peter and Paul day), Peter a Pavel rozsievajú huby (Záturecký, 2018, p. 516). Mnemonic, aimed at remembering the omen (Když se ríjen blýská, zima plíská (Great Slavic Calendar, 1913, p. 154); Svatý Vit príchází mliko pít (Vašků, 1998, p. 163); Když na Petra prší, bude moc myší (Bartoš, 1892, p. 81)), Ked' príde Vavrinec, ber oči na klinec. - Ked' príde Vavrinec, olovrant na klinec, Michal všetko z pol'a spíchal, Na Šimona Judy hájnici von z búdy; Na Šimona Judy mrznú v poli hrudy; Šimona Judy vyhán̆a baču z búdy (Záturecký, 2018, p. 516).

Other subfunctions, i.e. less regular, characteristic/uncharacteristic for one or another omen type, are regulatory-recommendatory, which reflects primarily the labour actions and processes regulation in connection with the names of patron saints, patrons or ethnometeorological periods (cf. in the Czech folk calendars: Svaty Prokop, zelí okop (Bartoš, 1892, p. 81)), Slovak. Na Urbanov deň utekaj siat' len (Flax must be sown on Saint Urban's Day), Po svätom Urbanu mráz neškodi džbánu (After Saint Urban, frost does not harm), Urban ešte niekedy bradou pokýva, Dokal Urban z pece nezleze, nebude teplo - By this proper name they correspond to other predictive functions: Kto sieje jeczmień na Urbana, będzie pił piwo ze dzbana, Slovak Pred Jánom nechvál jarinu, až po ňom (Before St. John do not praise spring, only after him) (Záturecký, 2018 , p. 515). Katarínu schovaj sa pod perinu (On St. Catherine's one should hide under the feather bed) (Záturecký, 2018, p. 518). Polish omens with this anthroponym correspond to the symbolism of utensils: Na Święty Jan jagod $d z$ ban (On St. John there is a jug of berries), $\mathrm{Na}$ Święty Jan przyniesie mleka pełen dzban/ oleju dzban (St. John will bring a jug of milk/jug of oil), etc. Polish Kto sieje jęczmień na Urbana, będzie pit piwo ze dzbana, Na świętego Urbana wszystka rola zasiana. Na Urbana chwile jakie, i lato takie, Po świętym Urbanie o zbożu gadanie, 
Pogoda na Urbana, deszcz na Wita, to dobrze na żyta (Krzyżanowski \& Swirko, 1972, p. 597).

The latter function is closely intertwined with cognitive, aimed at the development of human thinking, i.e. attention, memory, intuition, observation of human or animal behaviour, so-called means of transmission and decoding, reading "subtle knowledge" (Dř́v než kukačka zakuká, není zelený oves (Pavelka 1910, p. 314); Na den Obraceni svátého Pavla když voda stojí v koleji, šetřte v žlabě s ojedí (Vašků, 1998, p. 52) - in particular, the last omen contains a warning about the unfavourable weather situation and, as a consequence a long winter, and hence the need to save food, Slovak. Okolo sv. Doroty bývajú metelice a sloty. - Sv. Dorota - sneh alebo slota. Adalb. Dorota šw. (Záturecký, 2018, p. 520). The cognitive function of omens is intertwined with the function of knowledge accumulation, for example, in connection with ethnic stereotypes about Gypsies in Slovak signs: Cigán sa Hromníc bojí - Gypsies are afraid of thunder (p. 519).

There exist a lot of proverbial British omens concerning the days devoted to certain saints: Before St. John's Day, we pray for rain; after that, we get it anyhow. Rain on St. John's Day, and we may expect a wet harvest; Peter and Paul will rot the roots of the rye.; Bullion's Day, gif ye be fair, For forty days 'twill rain nae main; St. Swithin's Day, if ye do rain, For forty days it will remain St. Swithin's Day, an ye be fair, For forty days 'twill rain nae mair (Inwards, 1898, pp. 3238).

Often the linguistic-aesthetic subfunction shows the beauty of the linguistic embodiment (Kateřina šla do mlýna a namlela múky, plné klobúky (Niederle, 1918, p. 259); Na svatou Dorotu si jdou ptáci kupovat na ptači trh píštalky (Plicka, 1950, p. 104).

According to L. N. Vinogradova, the thematic basis of such instructive and prognostic formulas includes the field of folk regulations, "laws", "rules", explanations of causal relationships and dependencies corresponding to the traditional particular ethnic group worldview. Their verbal actualization is manifested in less stable forms, existing outside the rigidly established linguistic stereotypes" (Vinogradova, 1988, p. 278).

In the process of stereotyping experience, the recurring sign becomes a category of acceptance, for example, according to Russian perceptions in different regions, many boys are born before the war; there is a large harvest of grain, apples, mushrooms (Много грибов - много гробов Many mushrooms - many coffins). Researchers also note that variability and inconsistency are characteristic of omens: for example, the appearance of a rainbow in the sky may mean the end of rain or a prolonged downpour; the cry of an eagle on the roof of the house prophesies the illegitimate childbirth or the death of a family member (Agapkina \& Belova, 2009, p. 280).

It is stated that in ancient Greece and Rome, pine cones had a phallic significance, so they were symbols of fertility. It is interesting to record a superstition from the Highlands of Scotland stating that a lot of illegitimate births could be blamed on the large numbers of pine trees growing in the district (Begg). (Watts, 2007, p. 296).

V. K. Kharchenko and O. E. Tonkova (2008) propose to call thematic groups of signs, united by the basic concept-denotation, cryptoclasses, arguing that "... because the sign is based on the secret of the relationship between the event and its outcome, the designation "cryptoclass" is more accurate than the traditional "thematic group", "lexical-semantic class", etc." (pp. 38-39). Researchers distinguish four thematic groups or cryptoclasses of omens: calendar, meteorological, household and ritual.

Some calendar and meteorological features are organized on the principle of artefact symbols parametric organization related to the utensils and measurement units semantics and in general the cognitive container with the idea of large and small size; in this case, the predicted and the predictive contain a connection with such oppositions as many-little-big-small: Mnoho snehu, málo vody; Vel'ké snehy, málo vody (Záturecký, 
2018, p. 518), Malý sečeň protiví sa vel'kému (Záturecký, 2018, p. 519), barrel - spoon: $\mathrm{Na}$ jar cent dažd'a, funt blata. - Na jar za džbar dažd'a, za lyžicu blata. - Na jar za mericu dažd'a, za štvrtku blata. - Na jar za voz dažd'a, za hrst' blata. č. 446. Adalb. Maj 22, Wiosna 2. (Záturecký, 2018, p. 513). Polish omens have a similar structure: Na wiosnę ceber deszczu tyżka błota, na jesień tyżka deszczu - ceber błota (symbolic repositories - tyzka - ceber), In the spring, a bucket of rain is a spoonful of dirt, in the fall a spoonful of water is a bucket of dirt (the key parametric markers in these contexts are the sign conventional units of measurement of small magnitude: tyżka, garnek, ceber, kropla). Cf. also Polish.Czasem i w marcu zetnie wodę w garcu (Krzyżanowski \& Swirko, 1970, p. 396).

The symbolism of small and large can be coded by the names of animals, which is reflected in many signs of different peoples: Na Nový rok o slepači krok (New year is longer for a chicken step); na Tri krále o skok dale (Záturecký, 2018, p. 519), Rok je dlhý. - Rok má dlhý skok (Záturecký, 2018, p. 527). Similar methods were used to determine the time of year: the increase in the day after the winter solstice was measured by the displacement of the sun's rays in the house "chicken, hare jump", "o slepičí krok", "o zaječí skok", "o jeden vlas kohoutí" (Pohribna, 2011, p. 36). cf. Czech omen: Na Tři krále jest den delši o jeden hlas kohouti (On the Three Kings a day is one cock's crow longer) (Vašků, 1998, p. 44).

Cosmogonic omens include folk ideas and stereotypes about cosmic luminaries in different Slavic cultures (stereotype theory, what does an object look like, what is its colour, shape, substance, how it is related to other objects). Cf. Russian omen of the Amur region and Siberia: a formidable moon "the position of the moon horns up, which, according to folk signs, portends rainy weather", a similar sign is known to the Slovaks: Ked' je mesiac horerožky, bude čas pekný, ked' dolu rožky, bude dážd' (When horns of the moon up, there will be good weather, down - rainy) (Záturecký, 2018, p. 521). Russ. dry moon "the position of the moon, which according to folk omens portends clear, dry weather" (Mokienko, Nikitina, \& Nikolaeva, 2007, p. 398). In the vicinity of Perm, the expression the moon in mittens was recorded as "the moon, bordered by a strip of light, which, according to folk signs, portends frost" (Mokienko, Nikitina, \& Nikolaeva, p. 398). In Britain moon may influence the harvest: Plant the bean when the moon is light; Plant potatoes when the moon is dark (Inwards, 1898, p. 189).

Anthropomorphic omens associated with the human body, in particular the somatic code (Cryptoclass of the human body): HAIR, MOUTH, THROAT, HEELS, EARS, FEET; cf. Russ. The throat roars; growls in the throat (according to folklore omen predicts drinking spirits) (Mokienko, Nikitina, \& Nikolaeva, 2007, p. 129), Ukr. The right heel begins to itch when you need to quickly travel a long way [electronic version]; Do choho sverblyat' p'yaty: narodni prykmety ta zabobony (What heels itch: folk signs and superstitions) (What Heels Itch, 2019).

If sulfur boils in ears, the weather is going to be bad (Tambov, Novgorod, Vyatka) (Filin, 1977, p. 215), Ringing in ears, in winter signs heat, in summer - rain (Dal, 2003, p. 518).

British believed that the casual putting the left shoe on the right foot, or the right on the left, was thought anciently to be the forerunner of some unlucky accident (Brand, 1813, p. 488).

For example, the memory of the "chthonic" nature of the foot is already lost (the foot has acquired such "magical" properties due to its proximity to the ground, with its downward orientation, which explains the Permian saying 'go to the foot' - to die), but in some folk omens this symbolism still retains its survivability, for example, in the Ural, one cannot sweep the legs of a person sitting person or he will get sick (Podyukov, 1990, p. 57)

We can also talk about household signs-prescriptions and recommendations aimed at ensuring success, prosperity, wealth. For example, 
Russians in the Oryol region recorded an expression to sleep high (If You sleep high, you will be rich, if low - poor) (Filin, 1970, p. 25). Similar axiology is inherent in the beliefs and characteristics of other ethnic cultures, in which the semiotics of the top and bottom are manifested. This is especially true of childbirth and marriage magic, and so on. It is enough to turn to British beliefs, according to which, to ensure success, good luck to the child at birth, the last should be taken upstairs, to the highest place or to the room located in the house highest. This will contribute to the success of the child in the future life, promotion, career growth (Pickering, 1995, p. 17).

As you know, the top and bottom are one of the primary spatial semantic oppositions associated with popular ideas about the world - positive (good), top, negative - bad, bottom. For example, if a spider crawls upwards, it is a good sign, downwards - bad (Zhayvoronok, 2006, p. 79). According to the Ukrainian cultural tradition, on New Year's Eve, girls and boys foretold their destiny at the crossroads; to do this, they outlined a magic circle, sat in it, covered themselves with a white tablecloth and listened to the environment: from which side will be a sign hoarse barking of dogs.

Rarely the omen symbolism can be expressed verbally, in stable expressions: So, for example, according to Russian manifestations in Karelia, if a girl sits between two benches at the same time, which is called laying on crosses, she will not marry (Mokienko, Nikitina, \& Nikolaeva, 2007, p. 329), Ukrainian saying To drop the wedding ring means "to live unhappily or to divorce in the future. Based on the sign: "when during the registration of marriage one of the young people loses the wedding ring, it symbolizes an unhappy life, and even divorce in the future" (Uzhchenko \& Uzhchenko, 2005, p. 222).

According to A. V. Gura, the omen that a hare that has crossed the road or was met on the way promises misfortune to the traveller is noted among the Slavs everywhere. It is sometimes believed that a hare brings misfortune only when it runs down a mountain (Montenegrin) or crosses the road "behind the bosom" of a traveller (Brest). To avert misfortune, it is necessary, as the Southern Slavs believe, to return from the path, to wait for someone else to cross this road (Polish beliefs), to turn over three times on that place (Kharkov), to strike crosswise with a whip (the outskirts of Tarnow, Poland), three times to throw a handful of earth in the opposite direction to the hare (Lesser Poland), break the stick and throw one end to where the hare jumped out, and the other - to where he ran, etc. (Tolstoy, 1995b, p. 287). British also believed that it is very ill luck to have a hare cross one in a high way (Brand, 1813, p. 520).

Also, such a negative symbol in English omens is a pig running across the road: The swine has run through it 'about a failed marriage'; the expression goes back to the northern belief that a pig crossing the road of a wedding procession is a sign of failure: The swine has run through it, of a marriage gone wrong. (From the northern belief that it was unlucky for swine to cross the path in front of a wedding party) (Wilkinson, 1993, p. 397).

In traditional Ukrainian notions, the squirrel is an unclean animal, "it is a harbinger of fire, close to the house spirits, mermaids and other evil spirits. Meat of the last should not be eaten; meeting her is a bad omen" (Zhayvoronok, 2006, p. 39), similar prophecies are also known to Poles: Wiewiórka na dachu ogień zwiastuje (A squirrel on the roof of a house foretells fire) (Kobyliński, 1990, p. 203).

In determining the synoptic model of the world through the prism of the structure and semantics of calendar omens, in particular the cultural function of the name, scientists identify many different calendars, which are based on different principles of time management: solar, lunar, vegetative; Christian (church); agricultural, pastoral; family, etc. The Slavic, particularly the Russian folk calendar, is a combination of two main models - Christian and pre-Christian (agricultural in its direction). The combination of 
the two time systems is brought together in the popular consciousness Christian holidays with agrarian dates and seasons and the controlled work and life of the peasant. For example, the canvas for the folk calendar in the Slavic tradition (Russians, Ukrainians, Belarusians) were Orthodox saints, days of commemoration of Christian saints, and the names of these saints became the basis for remembering the dates of the beginning and end of agricultural work. For example, the day of the martyr Isidore (May 14/27) in the folk calendar - Cucumber Sidor: early cucumbers and flax were sown on Sidor. As a result of rethinking, saints often become patrons of time periods, and they are attributed special functions in connection with natural phenomena and human agricultural activity (Morgunova, Krivoshchapova, Osipova, 2014, p. 3).

\section{Conclusion}

As the study showed, individual signs can motivate the semiotic code of riddles, figurative and semantic structure of phraseological units and idioms (weather, meteorological signs about the family, marriage, related to animal behaviour, the guests' arrival, travel). Several omens contain in their semantic and figurative structure the cognitive function of the container (mainly the West Slavic tradition), associated with the units' parametric and symbolic structure (size semantics, much-little, large-small, short-long), utensils' symbolism (spoon-barrel, bucket-drop, full-empty, old-new, whole-broken), methods of measuring time through the names of animals (Ukrainian, Czech, Slovak signs), presented mainly in meteorological and household texts, related to the elements of folk cosmogony, primary archetypes and stereotypes of the sun, fire, water, earth, cosmic lights. Of particular note in this regard are anthropomorphic, usually phraseologised signs associated with the body, somatic code (crypto class of human body parts - hair, mouth, pharynx, heel, ears, legs, sound symbolism of a sonorous and hoarse voice in Russian consciousness), that of the pets, omes-instructions and recommendations aimed at ensuring success, well-being, wealth, which encodes the symbols of the top and bottom, positive and negative (English, Russian and Ukrainian omen texts) occur not so frequently.

Attention is paid to the principle of semantic attraction (attraction) in the omens of mythological and magical content in the predictive and predictable part of the omen; The peculiarities of the rites connected with the symbolism of ethnometeorological periods, calendar holidays and rites regulating labour and agricultural activity, the human life cycle, crafts, traditional occupations and crafts of the Eastern Slavs are covered. These motives contain economic and household recommendations (in connection to the annual cycle, months and other time periods), "unwritten rules", prohibitions, motivations for actions and customs, beliefs and other texts of instructive and prognostic orientation. As a rule, calendar sayings operate on the basis of norms for the Christian saints' commemoration days or in the names of saints "reading", which became the basis for regulating the beginning and end of agricultural or other types of work (e.g. spinning or weaving), harvesting. These units also occur in the Polish, Czech and Slovak models of the world. They are essential for understanding and deciphering the ritual and magical practice, allow to clarify the motivation and secondary meaning of symbolic actions and realities in the field of material and spiritual culture of the Slavs.

At the verbal level, this thematic group is represented primarily by chrononyms (the function of names in traditional folk culture), agionyms, geortonyms, denoting the names of the corresponding patrons. The attention is paid to the signs that are different in meaning and purpose, united around one anthroponym.

The analysis showed that these and other names, especially cultural anthroponyms associated with Christian ideology, undergo various reinterpretations in the traditional folk calendar due to accidental etymological convergence or 
transformation of the original religious or mythological content. This circle will be connected with the phenomenon of "folk-etymological magic" of the cultural text containing in different linguistic cultures connection to the axiology of favourable and unfavourable time, elements of internal and external space (the House and its parts), with spatial loci and borders, household, everyday objects, with marital and healing magic, inducing damage (cf. the functions of a broom, poker, chain, millstone, clothing, ritual bread and pastries), handicraft tools (spindle, reel, bird, potter's wheel, fishing net, etc., mainly in the Eastern Slavs beliefs), the concept of the Way and encounters with unclean animals (Slavic and British ideas about a hare or a pig crossing the road of a wedding procession or a traveller), the conceptual oppositions of clean-dirty, emptyfull.

\section{Acknowledgements}

The article has been prepared within the scope of the scientific project "Ecolinguistic Modes of Discursive Space of Ukraine in the European Multicultural Continuum" (registration number 2020.02/0241) with the support of the National Research Foundation of Ukraine (Igor Korolyov).

\section{References}

Afanasyev, A. N. (1988). Zhivaya voda i veshchee slovo (Living water and a prophetic word, in Russian). Moscow: Sovetskaya Rossiya.

Afanasyev, A. N. (1995). Poetichskie vozzreniya slavyan na prirodu. Opyt sravnitel'nogo izucheniya slavyanskikh predanii i verovanii v svyazi s mificheskimi skazaniyami drugikh rodstvennykh narodov (Poetic views of the Slavs on nature. Experience of comparative study of Slavic legends and beliefs in connection with the mythical legends of other re- lated peoples, in Russian). Moscow: Sovremennyi pisatel.

Agapkina, T. A., \& Belova, O. V. (2009). Primeta (Omen, in Russian). In N. I. Tolstoy (Ed.), Slavic antiquities: Ethnolinguistic dictionary (Vol. 4) (pp. 279-280). Moscow: Int. relations.

Balandina, N. F. (2003). Funktsional'no-prahmatychnyy ta linhvomental'nyy analiz cheskykh prahmatychnykh klishe (Functional-pragmatic and linguomental analysis of the Czech pragmatic cliché, in Ukrainian). (Doctoral dissertation). Kyiv.

Bartoš, F. (1892). Moravsky lid. Sebrané rozpravy z oboru moravské lidovědy (Moravian people. Collected debates from the field of Moravian folk science, in Czech). V Telči: Nákladem českého knihkupectví Emila Šolce.

Bayburin, A. K. (1990). Ritual: svoe i chuzhoe (Ritual: One's own and another's, in Russian). In B. N. Putilov (Ed.), Fol'klor i etnografiya. Problemy rekonstruktsii faktov traditsionnoi kul'tury (Folklore and ethnography. Problems of reconstruction of the facts of traditional culture, in Russian) (pp. 3-17). Leningrad: Nauka.

Brand, J. (1813). Observations on popular antiquities: Chiefly illustrating the origin of our vulgar customs, ceremonies, and superstitions. London: Printed for F. C. and J. Rivington.

Čečetka, F. J. (1900). Lidové názory o zjevech prrírodních (Folk views on natural phenomena, in Czech). Český lid (Czech people, in Czech), 3-4, 253-255.

Čelakovský, F. L. (2000). Mudrosloví národu slovanského ve príslovich (The wisdom of the Slavic nation in proverbs, in Czech). Praha: Lika Klub.

Chicherov, V. I. (1957). Zimnii period russkogo narodnogo zemledelcheskogo kalendarya XVI-XIX vv. (Winter period of the 
Russian folk agricultural calendar of the $16^{\text {th }}-19^{\text {th }}$ centuries, in Russian). Moscow: Izd-vo AN SSSR.

Chudzik, A. (2002). Mowne zachowania magiczne $w$ ujęciu pragmatycznokognitywnym (Language magic behavior in cognitive-pragmatic aspect, in Polish). Krakow: TaiWPN Universitas.

Dal, V. I. (2003). Tolkovyi slovar' zhivogo velikorusskogo yazyka: Sovremennoe napisanie (Explanatory dictionary of the living great Russian language: Modern writing, in Russian). (Vol. 1). Moscow: OOO Izdatel'stvo Astrel'.

Do choho sverbliat piaty: narodni prykmety ta zabobony (What heels itch: Folk omens and superstitions, in Ukrainian). (2019). Retrieved from https://ukr.media/esoterics/386597/

Fattakhova, N. N., Kulkova, M. A., \& Tuganova, S. V. (2014). Slovar' narodnykh primet v raznostrukturnykh yazykakh (russkii, tatarskii, angliiski, nemetskii) (Dictionary of folk signs in different-structured languages (Russian, Tatar, English, German), in Russian). Kazan: "Pechat'servis-XXI vek".

Filin, F. P. (Ed.) (1977). Slovar' russkikh narodnykh govorov (Dictionary of Russian folk dialects, in Russian). (Vol. 13). Moscow-Leningrad: Nauka.

Grzegorzczykowa, R. (1998). Profilowanie a inne pojęcia opisujace hierarhiczna strukturę znaczenia (Profiling and other concepts describing the hierarchical structure of meaning, in Polish). In J. Bartmiński, \& R. Tokarski (Eds.), Profilowanie w języku i tekście (Profiling in language and Text, in Polish) (pp.919). Lublin: UMCS.

Inwards, R. (1898). Weather lore: A Collection of proverbs, sayings and rules concerning the weather. London: Elliot Stock.

Ivanova, N. N (2005). Strukturno-semanticheskie osobennosti i lingvokul'turologicheskii potentsial primety (Structural and semantic features and linguoculturological potential of omens, in Russian). ( $\mathrm{PhD}$ Thesis, Pskov State Pedagogical University, Pskov, Russian Federation).

Jung, K. G. (1988). Ob arkhetipakh kollektivnogo bessoznatel'nogo (On the archetypes of the collective unconscious, in Russian). Voprosy filosofii (Problems of Philosophy, in Russian), 1, 137-144.

Kharchenko, V. K. (1992). Yazyk narodnoi primety (The language of folk omens, in Russian). Russkii yazyk v shkole (Russian Language at School, in Russian), 1, 78-82.

Kharchenko, V. K., \& Tonkova, E. E. (2008). Lingvistika narodnoi primety (Linguistics of folk omens, in Russian). Belgorod: Belgorodskaya oblastnaya tipografiya.

Khristoforova, O. B. (1998). K voprosu o strukture primety (On the question of the structure of omens, in Russian). Arbor mundi, 6, 1-23.

Kobyliński, S. (1990). Odpukajmy! Rzecz o ostrzegawczych przesadach polskich $z$ ilustracjami autora $i$ postowiem Wactawa Sadkowskiego (Let's knock on! A thing about warning Polish prejudices, illustrated by the author and an afterword by Wacław Sadkowski, in Polish). Katowice: Krajowa agencja wydawnicza.

Korolyova, A., \& Korolyov, I. (2020). Standardization of the formulas of discursive practice farewell in the national cooperative communicative behaviour. Valoda: nozime un forma. Gramatika un valodas normēšana (Language: Meaning and Form. Grammar and Language Standardization, in Latvian), 11, 77-92.

Krzyżanowski, J., \& Swirko, S. (Eds.). (1970). Nowa księga przystów $i$ wyrażeń przystowiowych polskich (A new book of polish proverbs and expressions, in 
Polish). (Vol. II). Warszawa: Państwowy Instytut Wydawniczy.

Krzyżanowski, J., \& Swirko, S. (Eds.). (1972). Nowa księga przystów $i$ wyrażeń przystowiowych polskich (A new book of polish proverbs and expressions, in Polish). (Vol. III). Warszawa: Państwowy Instytut Wydawniczy.

Levkievskaya, E. E. (2002). Slavyanskii obereg. Semantika i struktura (Slavic amulet. Semantics and structure, in Russian). Moscow: Indrik.

Levy-Bruhl, L. (1994). Sverkhestestvennoe v pervobytnom myshlenii (Supernatural in primitive thinking, in Russian). Moscow: Pedagogy Press.

Mashtakova, N. V. (2013). Natsionalno-kulturni osoblyvosti prysliviv z semantykoiu prykmet $\mathrm{u}$ riznostrukturnykh movakh (National and cultural features of proverbs with the semantics of omens in different structural languages, in Ukrainian). $(\mathrm{PhD}$ Thesis, National Pedagogical Dragomanov University Kyiv, Ukraine).

Mokienko, V., Nikitina, T., \& Nikolaeva, E. (Eds.) (2007). Bol'shoi slovar' russkikh pogovorok (Great dictionary of russian sayings, in Russian). Moscow: Olma Media Group.

Morgunova, O. V., Krivoshchapova, Y. A., \& Osipova, K. V. (2015). Russkii narodnyi kalendar'. Etnolingvisticheskii slovar (Russian folk calendar. Ethnolinguistic dictionary, in Russian). Moscow: AST-Press.

Muszyński, Z. (1998). Profilowanie profilowania (Profiling of Profiling, in Polish). In J. Bartmiński \& R. Tokarski (Eds.), Profilowanie w języku i tekście (Profiling in language and text, in Polish) (pp. 1935). Lublin: UMCS

Nazarova, I. Yu. (2007). Primety v professional'noi sfere (Omens in the Professional Field, in Russian). In E. R. Yarskaya-
Smirnova, \& P. V. Romanov (Eds.), Sotsialnyye transformatsii professionalizma: vzglyady snaruzhi. vzglyady iznutri (Social transformations of professionalism: Views from the outside, views from the inside, in Russian) (pp. 295-312). Moscow: OOO "Variant"; TsSPGI.

Niederle, L. (Ed.) (1918). Moravské Slovensko (Moravian slovakia, in Czech). (Vol. 1). Praha: Nákl. Národopisného musea českoslovanského.

Norman, B., \& Raynokhova, N. (2017). Primety i ikh verbalizatsiya $v$ traditsii dvukh slavyanskikh narodov: kulturologicheskii i pragmalingvisticheskii aspekty (Omens and their verbalization in the tradition of two Slavic peoples: Cultural and pragmalinguistic aspects, in Russian). Jazykovedný Časopis (Linguistic Journal, in Czech), 68(1), 5-16.

Pavelka, P. (1910). Př́sloví, pořekadla a jiné drobty z lidové řeči (Proverbs, sayings and other small genres in vernacular, in Czech). Český lid (Czech People, in Czech), 23, 312-314.

Petrichenko, O. A. (2003). Arkhetipcheskiye obrazy pervoelementov bytiya: predkontsept v mire vostochnykh slavyan i realizatsiya $\mathrm{v}$ avtorskikh tekstakh (na materiale poezii N. Gumileva) (Archetypal images of the primary elements of being: The preconception in the world of the eastern Slavs and implementation in the author's texts (based on the poetry of N. Gumilyov), in Russian). Slovyanskiy visnyk. Seriia "Filolohichni nau$k y$ ” (Slavic Herald: Series "Philological Sciences", in Ukrainian), 4, 127-130.

Pickering, D. (Ed.). (1995). Dictionary of Superstitions. Wellington House, London: Cassell.

Plicka, K. (1950). Český rok II (Czech year II, in Czech). Praha: Družstevní práce.

Podyukov, I. A. (1990). Narodnaya frazeologiya 
$v$ zerkale narodnoi kul'tury (Folk phraseology in the mirror of folk culture, in Russian). Perm: Permskii gosudarstvennyi pedagogicheskii universitet.

Pohribna, T. A. (2011). Semantyka ta prahmatyka nazv cheskykh narodnykh prykmet: linhvokulturolohichnyi pidkhid (The Semantics and Pragmatics of Czech Folk Omens: a Lingvocultural Approach, in Ukrainian). (PhD Thesis, O. O. Potebnya Institute of National Academy of Sciences of Ukraine, Kyiv, Ukraine).

Potebnya, A. A. (1989). Slovo i mif (Word and myth, in Russian). Moscow: Pravda.

Profantová, Z. (1986). Dúha vodu pije. Slovenské ludové pranostiky (The rainbow drinks water. Slovak folk weather omens, in Czech). Bratislava: Tatran̆.

Shakhnovich, M. I. (1984). Primety vernye i suyevernye. Ateisticheskie ocherki narodnogo znaniya i bytovogo suyeveriya (Faithful and superstitious omens. Atheistic sketches of folk knowledge and everyday superstition, in Russian). Leningrad: Lenizdat.

Shchepanskaya, T. B. (2010). Sravnitel'naya etnografiya professii: povsednevnye praktiki i kul'turnye kody (Rossiya, konets XX - nachalo XXI v.) (Comparative ethnography of professions: Everyday practices and cultural codes (Russia, late XX - early XXI centuries), in Russian). Saint Petersburg: Nauka.

Svoboda, O. (1901). Několik staročeských rad lékařských (Several old Czech medical advice, in Czech). Český lid (Czech People, in Czech), 4-5, 311-313.

Tolstoy, N. I. (1995a). Yazyk i narodnaya kultura. Ocherki po slavyanskoi mifologii i etnolingvistike (Language and folk culture. Essays on Slavic mythology and ethnolinguistics, in Russian). RAS Institute of Slavic and Balkan Studies. Moscow: Indrik.

Tolstoy, N. I. (Ed.). (1995b). Slavyanskie drev- nosti: etnolingvisticheskij slovar' (Slavic antiquities: An ethnolinguistic dictionary, in Russian). (Vol. 1). Moscow: Mezhdunarodnye otnosheniya.

Tsivyan, T. V. (1985). Mifologicheskoe programmirovanie povsednevnoi zhizni (Mythological programming of everyday life, in Russian). In A. K. Baiburin (Ed.), Etnicheskiye stereotipy povedeniya (Ethnic stereotypes of behaviour, in Russian) (pp. 154-179). Leningrad: Nauka.

Uzhchenko, V., \& Uzhchenko, D. (Eds.). (2005). Frazeolohichnyy slovnyk skhidnoslobozhans'kykh i stepovykh hovirok Donbasu (Phraseological dictionary of east Sloboda and steppe dialects of Donbass, in Ukrainian). Luhansk: Almamater.

Vašků, Z. (1998). Velký pranostikon (Great collection of folk weather omens, in Czech). Praha: Academia.

Velký Slovanský kalendár. Lidové pranostiky (Great Slavic calendar. Folk weather omens, in Czech). (1913). Praha-Karlín: Nakladatelství Rudolfa Storcha.

Vinogradova, L. N. (1988). Otrazhenie drevneslavyanskikh mifologicheskikh predstavlenii v "malykh" formakh (Reflection of ancient slavic mythological ideas in "small" forms, in Russian). In I. I. Kostyushko (Ed.), Istoriya, kul'tura, etnografiya i fol'klor slavyanskikh narodov. X Mezhdunarodnyy s'yezd slavistov (Culture, ethnography and folklore of the Slavic peoples. X international congress of Slavists, in Russian) (pp. 277-288). Moscow: Nauka.

Vinogradova, L. N. (2004). Verbalnye komponenty obryadovogo kompleksa (vliyaniye fol'klornogo teksta na strukturu, semantiku i terminologiyu obryada) (Verbal components of the ritual complex (the influence of the folklore text on the structure, semantics and terminology of 
the rite), in Russian). In S. M. Tolstaya (Ed.), Yazyk kultury. Semantika i grammatika. K 80-letiyu so dnya rozhdeniya akademika Nikity Ilicha Tolstogo (1923-1996) (Language of culture. semantics and grammar. On the occasion of the $80^{\text {th }}$ birthday of Academician Nikita Ilyich Tolstoy (1923-1996), in Russian) (pp. 217-236). Moscow: Indrik.

Watts, D. (Ed.). (2007). The dictionary of plant lore. United Kindom, Amsterdam, Boston, London, New York, Oxford: Elsevier Science Publishing Co Inc.

Wilkinson, P. R. (1993). A thesaurus of traditional English metaphors. London; New York: Routledge.

Wright, E. M. (1913). Rustic Speech and Folklore. London: Humphrey Milford Oxford University.

Záturecký, A. (2018). Slovenské príslovia, porekadlá, úslovia a hádanky (Slovak Proverbs, sayings, utterances and riddles, in
Slovak). Bratislava: Tatran.

Zavyalova, E. E. (2013). Primety kak fol'klornyi thanr (Omens as a folklore genre, in Russian). Problemy filologii, kul'turologii i iskusstvoznaniya (Problems of Philology, Culturology and Art Studies), 2, 187-193.

Zelenin, A. V. (2014). Kak svistyat russkie (How the Russians whistle, in Russian). Russkiy yazyk v shkole (Russian at School, in Russian), 1, 77-84.

Zhayvoronok, V. (2006). Znaky ukrayins'koyi etnokul'tury. Slovnyk-dovidnyk (Signs of ukrainian ethnoculture. Directory dictionary, in Ukrainian). Kyiv: Dovira.

Zhuykova, M. V. (2007). Dynamichni protsesy u frazeolohichniy systemi skhidnoslov'yans'kykh mov (Dynamic processes in the phraseological system of the eastern Slavic languages, in Ukrainian). Lutsk: Vezha. 